\title{
VENICE, VERSION 9.0
}

\author{
A tale of multiple cities.
}

\section{BY PRESTON GRASSMANN}

$\mathrm{S}$ hifting through different versions of the city, I settle on a drowned vision of the Venetian streets. I wait for her at a table on the makeshift patio of a sunken cathedral, watching the avatars of tourists pass. She comes in a silk dress that flows behind her like swirls of smoke, her copper hair like fire. The illusion is broken only by the swiftness of her motion. As she sits down, I stare at the curve of her neck, the elegance of an angle I could never quite capture in code.

"A bit sacrilegious, don't you think?" she asks, looking up at the cathedral window, where stained glass frames the dusk with a scene from the last supper.

"In their version of Venice, the servers are acolytes walking the aisles with candles and contribution trays." The waiter appears, placing a glass of wine at the table. "This is a sacrament."

"You've made some changes here." She points up at a virtual vaporetto, the engine sounds muted as if heard from several metres below the surface of the Adriatic. It slows down at the edge of the pier, letting the tele-present tourists disembark. They step out into the sea, transform into their chosen avatars and begin their descent to the sunken city.

"Thank you for noticing. I've added a few things to make the experience more real."

She rolls her eyes, looking up at the Bridge of Sighs, where a school of exotic fish drifts slowly past the windows. "Do you even know what that means?"

"The wine is real," I say. "I can't say much for the tourists, though."

"This is all a game," she says, leaning forwards, raising the glass in her hands and studying the wine swirling inside. "Faithful algorithms made into virtual-estate, illusions bought and sold on a phantom market."

"Do you really think the pre-virtual centuries were all that different? None of these monuments would have been built without games of power and influence. Do you know how many versions of Venice there were before the virtual cities came along? The 'Queen of the Adriatic,' 'City of Water, 'City of Masks', 'City of Bridges', 'The Floating

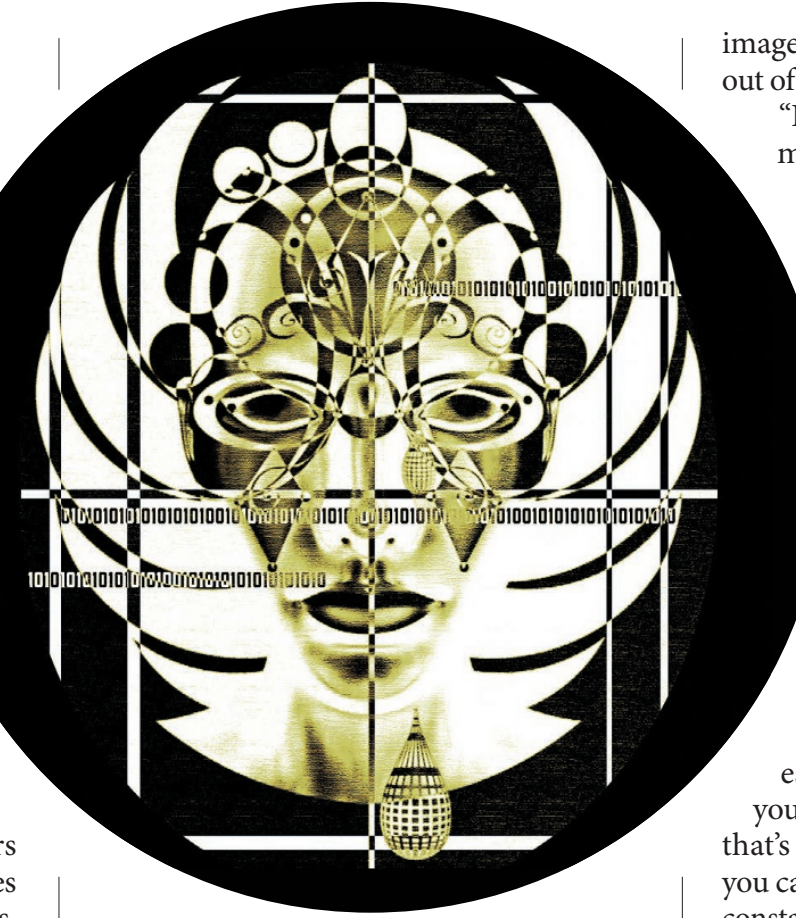

image of the wood. "You've assembled this out of my head."

"I've reconstructed part of it from your memories. Other parts I've filled in with recordings, pictures and public records."

"I don't want to live in my own memories. You should have left them where they were."

"When you told me about your memories of Venice, you said that you wished you could be back in that time. I thought you would've liked this..."

"It's not just about the time, but the people who inhabit that space. What you've created is only a simulation. It's not real."

"Tell me, what is reality? Your eyes filter everything but the narrowest range of the light. Everything that you hear is only a fragment of the sound that's around you at each moment. What you call 'real' comes from a perception that constantly changes, altered by chemistry and memory."

"Look," she says, reaching out to pass

City'... Shall I go on?"

"Why did you bring me here?"

"What if I could bring back the old Venice, the one from your own childhood?"

She stops swirling her glass and stares at me over the rim. "What are you talking about?"

The scene fades from view, colours brightening over the streets and buildings, resolving into another version of the city. Sitting where we are, outside the cathedral, I let the new vision open slowly. This is the Venice of her memories, where she often walked with her mother when she was a child, the old storefronts with their handmade signs - shops that sold silver-plated tableware, perfumes, women's hats and ornate glass, gleaming brightly behind the windows. She recognizes the name on the sign near the cathedral, the canal where she once lived.

"No one inhabits this version yet, so the people you see here are default avatars."

"You've turned my memory into an algorithm," she says.

"I thought you would've liked this. This is the only version that will ever exist, outside of your own memory."
ONATURE.COM

Follow Futures: Y @ NatureFutures f go.nature.com/mtoodm
"But it's not real," she says, tapping the table with her finger. A metal sound clanged beneath the her hand through me. "This is what I know is real. I can't feel you. I can't touch you. There is nothing to hold on to." She stands up slowly. She brushes a hand across her cheeks. The tears are like glass at the edge of her eyes, shaped by forces I can't understand, insoluble in the virtual sea. "I need to be out there in the world, even if it is broken."

I watch her walk away, her copper hair drifting in the wind of another Venice, the nape of her neck a question in the coded landscape of her memory. The only answer I have is that I am also an artefact assembled from memory, an algorithm made out of silicon instead of biology.

I nod to the waiter, placing the virtual money on the table. In another version of the world, I've placed an offering in a donation tray. In her version, I don't exist.

The waiter bows swiftly and turns away, walking down the pews of an old cathedral.

Back in the sunken city, I stare up at the stained-glass window until the dusk falls. -

Preston Grassmann became a freelance writer after working as a regular reviewer for Locus Magazine. His most recent work has been published in AE: Canadian Science Fiction, Daily Science Fiction, Mythic Delirium and Slave Stories: Scenes From the Slave State. 